\title{
Darwin taxonomist: Barnacles and shell burrowing barnacles
}

\author{
Darwin taxónomo: cirrípedos y cirrípedos perforadores de conchas
}

JUAN CARLOS CASTILLA

\begin{abstract}
Departamento de Ecología \& Center for Advanced Studies in Ecology and Biodiversity (CASEB), Facultad de Ciencias Biológicas, Universidad Católica de Chile, Casilla 114-D, Santiago, Chile e-mail: jcastilla@bio.puc.cl
\end{abstract}

\begin{abstract}
This bibliographic review revisits circumstances in which the wharf, shell burrowing barnacle, Cryptophialus minutus, was first collected by Charles Darwin in southern Chile, in 1836. Further, explores how its collection marked Darwin's taxonomical interest in Cirripedia. A short review analyzes the initial number of extant species of Cirripedia, as described by Darwin and the present situation, with emphasis on recent collections of C. minutus in the southern tip of South America.
\end{abstract}

Key words: Chile, Darwin, dwarf barnacles, shell burrowing barnacles.

\section{RESUMEN}

Esta revisión bibliográfica describe las circunstancias en el que el cirrípedo enano, Crypophialus minutus, perforador de conchas, fue recolectado por Charles Darwin en el sur de Chile, en 1836. Además, cómo esta recolección marcó el interés taxonómico de Darwin en Cirripedia. Se presenta una revisión resumida sobre el número inicial de especies vivas de Cirripedia, como fueron descritas por Darwin, y la situación actual, con énfasis en recolecciones recientes de C. minutus en el cono sur de Suramérica.

Palabras clave: Chile, cirrípedos enanos, cirrípedos perforadores de conchas, Darwin.

DARWIN AND THE DISCOVERY OF THE

"LITTLE FELLOW"

January $1^{\text {st }}, 1835$

The southern end of the Archipelago de los Chonos, Taitao Peninsula, Chile. The warship HMS Beagle is anchored at Tres Montes Gulf, under the command of Captain Robert FitzRoy, enduring north-east winds of hurricane proportions. Charles Darwin, familiar with southern hemisphere storms, reflects: "Thank God, we are not destined here to see the end of it, but hope then to be in the Pacific Ocean, where a blue sky tells one there is a heaven, a something beyond the clouds above our heads".
January $7^{\text {th }}, 1835$

Two weeks after the storm, a 24 year old Darwin walks along the rocky intertidal at Bahia Low (4348'30" S; 7303'05” W), Isla Gran Guaiteca, collecting samples. An empty shell of the Chilean edible mollusc, known as "loco", catches his eye. Although he has probably observed many of them in Chile, this shell is different; it is covered with hundreds of millimetre sized perforations. He identifies the shell as Concholepas Peruviana (Darwin 1854a); but nowadays we know that there is one species of this genus: Concholepas concholepas (C. Peruviana became synonymous). Once back in his cabin on the Beagle, curiosity makes him to scrutinize the Concholepas shell under the 
microscope. With the help of a needle he discovers dozens of small organisms, a few millimetres long, living inside the orifices. After removing them they appear ochre coloured and curved. Darwin, with experience in marine invertebrates, recognizes the basic anatomy as that of a crustacean barnacle. However, he knows that barnacles secrete thoracic calcareous plates and these little fellows are shell-less; moreover, barnacles are sessile organisms and do not burrow into shells. Darwin fixes the shell pieces in alcohol and labels the samples as "barnacles Balanidae". He is unaware of the scientific outcomes resulting from these observations. They will represent a crucial stage of his future career, a trail lasting eight years, between 1846 and 1854, dedicated to taxonomy, pursued with passion, obsession and anxiety, finally crowned with the award of the Royal Medal of the Royal Society of London in 1854.

\section{October 1836}

Back in England, these barnacle specimens will become one of Darwin's obsessions: Are they really barnacles? The thoracic segments do not appear to have appendages, as usual in barnacles, but instead they arise from the abdominal segments. Are they related to the sessile balanid or to the pedunculated Lepadidae? Are they burrowing into the shells mechanically or do they secret dissolving substances? Are they hermaphrodites as are all other known barnacles? Certainly this is a new species and Darwin assigned it a fantasy name: Mr. Arthrobalanus, "the little fellow". It will take Darwin several years to solve these questions.

\section{October 1846, Down House, Kent}

Darwin is starting his taxonomic saga on the live and fossil barnacles of the world. In his autobiography (edited by Barlow 1958) he comments: "...When on the coast of Chile, I found a most curious form, which burrowed into the shells of Concholepas, and which differed so much from all other Cirripedes that I had to form a new-sub-order for its sole reception. To understand the structure of my new Cirripede (underlining by the author) I had to examine and dissect many of the common forms: and it gradually led me on to take up the whole group. I worked steadily on the subject for the next eight years".

During the 8 years he dedicated to the taxonomy of the group, at that time scarcely known, Sub-class Cirripedia (Crustacea), Darwin confirms and re-affirms: (a) the beauty of homologies (similar structures that result form a common ancestor); (b) the greatness of the adaptation processes and implications of variability; (c) his ideas on the meaning and significance of a "System of Natural Classification", which he repeatedly used in "The Origin of Species" (see chapters IV and $\mathrm{XV}$ ); (d) the consequences of the natural selection mechanism, through characteristics of divergence (and extinction) and, centrally for Darwin, the descent from common lineages (see below); (e) Some of the fundamental principles of his theory of evolution related to the dynamics of speciation (nevertheless, these last two points are strongly debatable, see below).

Darwin's conclusion based on the available evidence is that undoubtedly, the Cirripedia belonged to the Class Crustacea (being a SubClass), which was in line with William Vaughan Thompson's 1830 work on the larval development of the group. Previously, Linnaeus and Cuvier had considered barnacles as mollusks. In the same vein, in 1782 the Chilean Abad Juan Ignacio Molina described the Chilean edible giant barnacle ("picoroco") as Lepas psittacus (Molina, 1782, page 223; nowadays Austromegabalanus psittacus), as a member of the group Vermes, Testacea (Linnaeus 1767).

At the beginning of his work on barnacles Darwin knew, due to the fossil record, that the stalked barnacles (Lepadidae) were, in evolutionary terms, the older group in the lineage. Accordingly, he began his taxonomic work with them, on samples collected during the voyage of the Beagle and with the many collections provided by specialists from museums worldwide. Darwin would not initiate his taxonomic work with his most compelling questions concerning $\mathrm{Mr}$. Arthrobalanus. Before going back to the questions he previously pursued an exhaustive knowledge of the known fauna of Cirripedia.

The monograph on living barnacles of the Family Lepadidae (Order Thoracica) was Darwin's first in-depth contribution to Cirripedia. It was started in 1846 and published 
in 1851 (Darwin 1851a). The work comprised 400 pages and 10 plates illustrated by George Sowerby. The study describes all the relevant aspects of the taxonomy of Cirripedia: characterizations, exhaustive anatomic descriptions of the plates and internal structure (muscles, folds), larval stages, cirri and appendages, reproductive, circulatory and nervous systems, biogeography and paleontology. Darwin described 46 species for this family, of which 17 were new species. Two new genera were also proposed. His monograph on fossil Lepadidae from Great Britain was published in the same year (Darwin 1851b).

By 1854 Darwin completed and published the monograph on living sessile barnacles Balanidae and Verrucidae (Darwin 1854a). This volume comprises 684 pages and 30 plates. Darwin described 108 species within the Balanidae and Verrucidae families, out of which 45 were new species. Moreover, in this volume he described two new Orders: Abdominalia and Apoda, each one with only one species. Also in 1854 he published the monograph on British Balanidae and Verrucidae fossils from Great Britain (Darwin 1854b). Altogether, the four monographic volumes on barnacles, included more than 1,200 pages and 47 plates with hundreds of illustrations (all the species were illustrated!).

In 1854, and primarily for his monographs on live barnacles, Darwin was awarded the Royal Medal of the Royal Society of London in 1854. In this way he became a well-known and reputable taxonomist, both at home and overseas. Most likely, without this strong scientific scholarship, together with his widereaching scientific ideas derived from his taxonomic work, the acceptance of his book on the Origin of Species would have been different (Stott 2003).

Personally, I believe that the Cirripedia was one of the richest sources of biological material available to Darwin to initiate an exhaustive study, and test some of his central hypotheses concerning evolution. Being a professional taxonomist, Darwin was compelled to define taxonomic limits, he was forced to make crucial decisions on the anatomical homologies and larval development of Cirripedia and he was able to define Orders, Families and Genera. I consider that the historical significance of Darwin's work on the
Cirripedia has not been fully acknowledged. At the time, he shared his findings with enthusiasm with fellow scientists including Professor Joseph Hooker and Dr. John E. Gray in Great Britain, Professor H-Milne Edwards in France and Professors James D. Dana and Louis Agassiz in the USA. However, in his book "The origin of species by means of natural selection or the preservation of favoured races in the struggle for life" (1859), the findings and concepts born from the study of Cirripedia are seldom cited, but nonetheless reflected in a most relevant quotation: "Pedunculated cirripedes (Lepadidae) have two minute folds of skin, called by me the ovigerous frena, which serve, through the means of a sticky secretion, to retain the eggs until they are hatched within the sac. These cirripedes have no branchiae, the whole surface of the body and the sac, together with the small frena, serving for respiration. The Balanidae or sessile cirripedes, on the other hand, have no ovigerous frena, the eggs lying loose at the bottom of the sac, within the well-enclosed shell; but they have, in the same relative position with the frena, large, much-folded membranes, which freely communicate with the circulatory lacunae of the sac and body, and which have been considered by all naturalists to act as branchiae. Now I think no one will dispute that the ovigerous frena in the one family are strictly homologous with the branchiae of the other family; indeed, they graduate into each other. Therefore it need not be doubted that the two little folds of skin, which originally served as ovigerous frena, but which, likewise, very gradually converted by natural selection into branchiae, simply through an increase in their size and the obliteration of their adhesive glands. If all pedunculated cirripedes had become extinct, and they suffered far more extinction than have sessile cirripedes, who would ever have imagined that the branchiae in this latter family had originally existed as organs for preventing the ova from being washed out of the sac?" (underlining by the author). The morphological and physiological concepts in the above paragraphs are enlightening. There is a perfect and logical use of the homology concept, gradual changes, and natural selection mechanisms. Moreover, the final question is brilliant and portrays some of the beauty of Darwin's book. 
What about Mr. Arthrobalanus?

Darwin predicted: "To understand the structure of my new cirripede (the little fellow) I had to examine and dissect many of the common forms". Only after that, in the final pages of his monograph on living sessile cirripedes (Darwin 1854a), he was able to sort out the taxonomic puzzle of Low Bay. Taxonomically, "Mr. Arthrobalanus" was no doubt a barnacle, but it was so different from all other known barnacles that Darwin had to establish a new Order: Abdominalia, to accommodate the new species, designated as Cryptophialus minutus (Fig. 1; see illustrations in Darwin 1854a, plates 23 and 24, and Tomlinson 1969a).

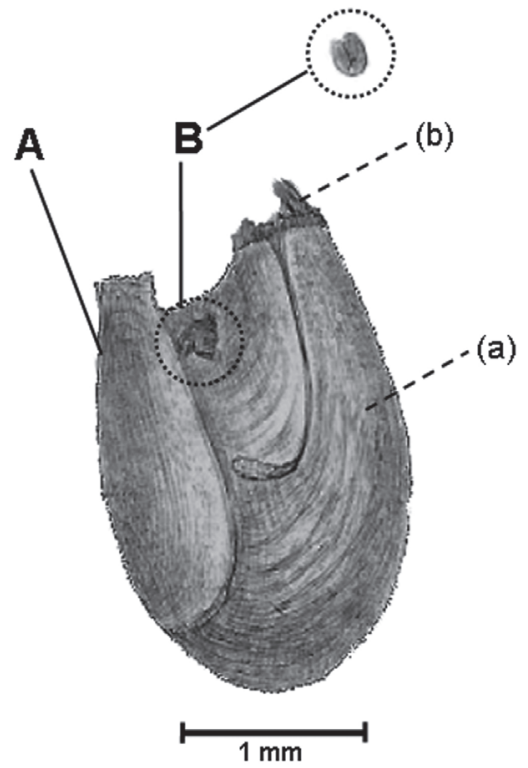

The first microscopic dissections of $C$. minutus, carried out at Down House, revealed that all the specimens $(2.5-3.0 \mathrm{~mm})$ originally extracted from the shell of Concholepas were females. Thus, differing from the almost universal hermaphroditism described in the literature for Cirripedia, Cryptophialus had separate sexes. It took Darwin longer time to discover the males, since they were very tiny $(0.28-0.30 \mathrm{~mm})$ and appeared as parasites cemented next to the antenna of the females. These males, together with a similar one described in 1849 (Hancock 1849), became the world's smallest barnacles ever described. Darwin found 2-7 C. minutus males cemented to each female, each with the task to fertilize

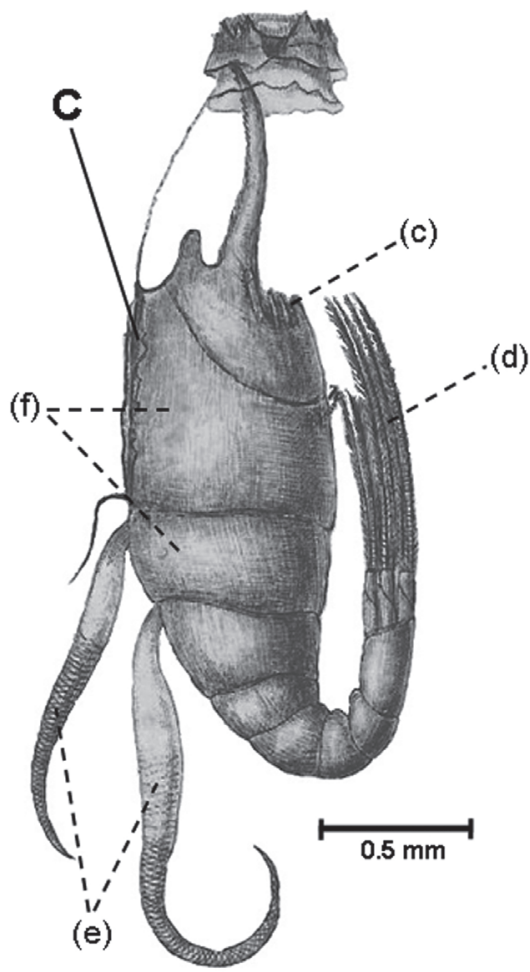

Fig. 1: Cryptophialus minutus Darwin, 1854. A. Lateral view of a female inside the mantle (ochre); maximum length: $2.5-3.0 \mathrm{~mm}$. B. Male (inside the circle) attached to free worn edge of the mantle (1-7 attached males per female); maximum length of males: $0.28-0.30 \mathrm{~mm}$. C. Lateral view of shellless female removed from the mantle: (a) mantle or tunic encapsulating the female; (b) aperture ornaments and entrance to the internal mantle cavity; (c) maxillae; (d) three pairs of thoracic cirri; (e) dorsal body appendages; (f) body segments (modified from Darwin 1854a; denominations according to Tomlinson, 1969).

Cryptophialus minutus Darwin, 1854. A. Vista lateral de la envoltura o manto (color ocre) que encierra un ejemplar hembra; largo máximo: 2.5-3.0 mm. B. Un ejemplar macho (en el círculo) adherido al borde libre del manto (1-7 machos se adhieren por hembra); largo máximo de un ejemplar macho: 0.28-0.30 mm. C. Vista lateral de un ejemplar hembra removido desde el manto: (a) manto o túnica que envuelve a la hembra; (b) ornamentos y orificio de entrada al interior de la cavidad del manto; (c) maxilas; (d) tres pares de cirros toráxicos; (e) apéndices dorsales del cuerpo; (f) segmentos del cuerpo (modificado de Darwin, 1854a; denominaciones según Tomlinson, 1969). 
approximately 60 eggs. Their penis reached 8-9 times their total length. Similar dwarf males were described by Darwin in specimens of the genus Ibla and Scalpellum of the Lepadidae family. Moreover, Darwin found dwarf males cemented to the hermaphrodite barnacle Scalpellum quadrivalvis, referring to them as "complemental males".

In Stott's view (Stott 2003), as a result of these discoveries, Darwin was once more astonished: "Again he was reminded about the usefulness of his species theory for he would never have been led to investigate the Ibla and thus discover the complemental males if he hadn't already had an idea that separate sexes had evolved from hermaphrodite forms. He was plotting a bloodline in these books [Cirripedia] starting from the ancient hermaphrodite Pollicipes, through the Ibla and Scalpellum to the recent stalked barnacles: diversification and variation, branching and splitting". Summing up, in his taxonomic work Darwin was faced with a large majority of hermaphrodite barnacles, but also with taxa with separate sexes. He was able to differentiate significant anatomical and functional modifications (such as dwarf males) and finally identified hermaphrodite barnacles bearing complementary dwarf males. It was the first time that such complete sexual assortment was found in the animal kingdom; though, as noted by Darwin, such assortment is common in the plant kingdom.

In 1837 , at 37 year old, when Darwin decided to start his work on the Cirripedia monographs, he had already dedicated several years to prepare a manuscript concerning his theory on the origin and mutability of species, the descent from common ancestors and the natural selection mechanism. In 1846 he decided to set aside temporarily a 231 pages manuscript presenting his theory of evolution. He thought that the time was not appropriate for his audacious ideas and he gave instructions to his wife Emma about how to publish it in case of his death. It was a family secret. Presumably, he felt a compelling need to further corroborate his ideas and hypotheses in a practical way, with additional evidence from taxonomic and field observations. In my view, the Cirripedia work paved the way and provided Darwin with the conviction, and confidence, he needed for the final publication of his theory on the origin and mutability of species. I consider that at the time (and probably today), Charles Darwin's four monographic volumes on Cirripedia represented four jewels in a crown carved with passion, obsession and pain by a great engraver: the best.

AFTER DARWIN: CIRRIPEDIA, SHELL BURROWING BARNACLES AND CRYPTOPHIALUS MINUTUS

One century and a half after Darwin's monographs on extant barnacles were published, his initial count of 156 species has increased to 1,009: Super-order Thoracica, Order Pedunculata: 484; Order Sessilia: 464; Super-order Achrothoracica: 61. The Acrothoracica (sensu Newman 1996), to which the shell burrowing barnacles belong, has been divided into the Order Pygophora (alimentary canal complete, with anus), with 54 species, including 9 species of Cryptophialus, and the Order Apygophora (alimentary canal incomplete, without anus), with 7 species.

Crytophialus minutus is still a valid species with one synonymy: Cryptophialus striatus Berndt 1903. Gruvel (1905) established that the origin of the cirri of the terminal body segments of $C$. minus was thoracic and not abdominal, as was erroneously assumed by Darwin (also see Deutsch, 2009). Accordingly, he changed the denomination of the Order Abdominalia, established by Darwin, to the Order Acrothoracica and incorporated within it the four known genera of shell burrowing barnacles: Alcippe (Hancock 1849), Cryptophialus (Darwin 1854), Kochlorine (Noll 1872) and Lithoglyptes (Aurivillius 1982). Since then, mainly in the 1950 's, at least five new genera have been added to Acrothoracica (Tomlinson 1969a, 1987).

Since Darwin's collection of $C$. minutus, the species has been reported several times (Tomlinson 1969a, b). Tomlinson (1969a) summarized the knowledge about the hosts and distribution of C. minutus as follows: (1) Dried specimens removed from shells of the muricid gastropod "loco", Concholepas concholepas: (a) by Darwin in 1836 at Low Bay, Chile, (b) nine specimens removed from locos in local market in Santiago, (c) six specimens removed from locos in Ushuaia, Argentina, Beagle Channel. (2) Specimens removed from shells of 
Chiton magnificus from Chile (unreported location), Berndt (1903). (3) Presence of $C$. minutus based on gastropod shell empty slits "without recognizable specimens" from: (a) Acanthina (Chorus) gigantea, Talcahuano, Chile, (b) C. concholepas, Pucusana, approximately $60 \mathrm{~km}$ south of Lima; (c) $C$. concholepas, Puerto San Antonio, Chile; (d) Fissurella maxima, Valparaíso, Chile (photos of C. minutus slits in shells of C. concholepas and F. maxima in Tomlinson 1969b).

C. minutus is the only Acrothoracica barnacle described from the South-eastern Pacific (and Beagle Channel) and it appears to have a preference for burrowing shells of $C$. concholepas. Further, as described by Tomlinson (1969b), the burrows are normally made in dead shells, with initial burrowing aided by enzymatic softening, followed by abrasion. Within the family Crytophialidae, the main burrowed shells are those of the gastropods Concholepas, Turbo, Acanthina, Thais, Haliotis, Fissurella; the bivalve Tridacna; chiton; corals such as Acropora and shells of Balanus (Tomlinson 1969a).

\section{DARWIN TAXONOMIST}

Darwin's long-lasting impact on evolutionary theory has meant that his scientific work has been carefully scrutinized. His taxonomical views on barnacles and the meaning of "Natural Classification" have been open to discussion. Ghiselin \& Jaffe (1974), and particularly Mayr (1982, 1994, 1995), have argued that Darwinian classification endeavours involved the dual criteria of genealogy and the degree of similarity among and between species. On the contrary, Nelson (1974), Desmond \& Moore (1991), and particularly Padian (1999), have argued that Darwin insisted only on genealogy and that he can not be considered the founder of evolutionary taxonomy. Padian (1999) summarized his views arguing that Darwin's monographs on barnacle classification used similarities between and among species of barnacles, not to construct phylogenies, but rather to reveal the common ancestry on which they should be based. Darwin's barnacle monographs contained a conventional taxonomy that addressed issues of his days.
According to Padian, Darwin can not be considered a cladist, at least in the way cladists have developed their theories later, since the early 1970's (Nelson 1974). So, looking into his barnacle monographs, nowhere did Darwin discussed the relationship between evolutionary theory and systematic, and nowhere he did explicit a Darwinian philosophy of classification. Mayr (1982, 1995) disagrees.

To me, from a taxonomist point of view, it is essential to recognize that Darwin was a man living in the mid 1800's and his writings need to be placed in that context and time. Nevertheless, one wonders whether Darwin's pride and frustration with the barnacle monographs is imprinted in his autobiography (Barlow 1958) when he recalled: "The Cirripedes form a highly varying and difficult group of species to class; and my work was of considerable use to me, when I had to discuss in the Origin of Species the principles of a natural classification. Nevertheless, I doubt whether the work was worth the consumption of so much time". The last part of this sentence has been recurrently used to signal that perhaps Darwins's taxonomical work on Cirripedia was not as critical in his scientific career as I personally view it. Perhaps it is important to notice that Darwin wrote down his recollections for his own amusement and interests of descendants in 1876 . His autobiography was published as part of "Life and letter of Charles Darwin", edited by his son Francis in 1887, five years after Darwin's death; see Barlow 1958). Nevertheless, undoubtedly during the time Darwin worked on Cirripedia he was "in love" with the group (as professional taxonomists are with their group!). Barnacles and Darwin's species theory were side by side. As a proof, this is part of the letter Darwin sent to J.D. Hooker in May 1848: "I have been getting on well with my beloved cirripedia, and got more skilful in dissection: I have worked out the nervous system pretty well in several genera, and made out their ears and nostrils, which were quite unknown. I have lately got a bisexual cirripede, the male being microscopically small and parasitic within the sack of the female; I tell you this to boast of my species theory, for the nearest and closely allied genus to it is, as usual, hermaphrodite, but I had observed some minute parasites adhering to it, and these parasites, I now can 
show, are supplemental males, the male organs in the hermaphrodite being unusually small, though perfect and containing zoosperms: so we have almost a polygamous animal, simple females alone being wanting. I never should have made this out, had not my species theory convinced me that a hermaphrodite species must pass into a bisexual species by insensibly small stages and here we have it, for the male organs in the hermaphrodite are beginning to fail, and independent males ready formed. But I can hardly explain what I mean, and you will perhaps wish my Barnacles and Species theory al Diabolo together. But I don't care what you say, my species theory is all gospel" (underlining by author).

\section{ACKNOWLEDGEMENTS}

I sincerely acknowledge the help of my wife during bibliographic review and suggestions made on early mss by S. Navarrete, P. Manríquez, M. Lee, J. Armesto and D. Wethey. The help of Veronica Ortiz is greatly acknowledged. My friend Bill Newman, Scripps Institution of Oceanography, illuminated the quest for Cryptophialus minutus. Correspondence with Dr. Fabio Bettinni Pitombo, Niteroi, Brazil, was very useful. This paper was orally presented, May 2009, in a session of the Academia Chilena de Ciencias, Instituto de Chile.

\section{LITERATURE CITED}

BARLOW N (ed) (1958) The autobiography of Charles Darwin: 1809-1882. W.W. Norton \& Company, New York. 253 pp.

DARWIN CR (1851a) A monograph on the Sub-Class Cirripedia, with figures of all the species, Lepadidae or pedunculated cirripedes. Volume I. The Ray Society. C. and J. Adlard, Printers, Bartholomew Close, London, UK. 400 pp. \& 10 plates.

DARWIN CR (1851b) A monograph on the fossil Lepadidæ or pedunculated cirripedes of Great Britain. Palæontographical Society. C and J. Adlard, Printers, Bartholomew Close, London, UK. 86 pp. \& 5 plates.

DARWIN CR (1854a) A monograph on the sub-class
Cirripedia, with figures of all the species. The Balanidae (or sessile cirripedes; the Verucidae, etc.). Volume II. The Ray Society. C. and J. Adlard, printers, Bartholomew Close, London, UK. 684 pp. \& 30 plates.

DARWIN CR (1854b) [=1855] A monograph on the fossil Balanidae and Verrucidae of Great Britain. Palæontographical Society. C and J. Adlard, Printers, Bartholomew Close, London, UK. 44 pp. \& 2 plates.

DARWIN CR (1859) On the origin of species by means of natural selection or the preservation of favoured races in the struggle for life. Introduction by $\mathrm{Sir}$ Julian Huxley. Mentor Books, 1958. The American Library and the New English Library Limited, London, UK. 479 pp.

DESMOND AJ \& J MOORE (1991) Charles Darwin: The life of a tormented evolutionist. Warner, New York. $800 \mathrm{pp}$.

DEUTSCH, JS (2009) Darwin and the cirripedes: Insights and dreadful blunders. Integrative Zoology 4: 316322.

ZGHISELIN MT \& L JAFFE (1974) Phylogenetic classification in Darwin's monograph on the Subclass Cirripedia. Systematic Zoology 22: 132-140.

GRUVEL A (1905) Monographie des cirrhipèdes our Thécostracés. Masson and Cie., Paris. 472 pp.

HANCOCK A (1849) Notice of the occurrence on the British coast of a burrowing barnacle belonging to a new order of the class Cirripedia. Annals Magazine of Natural History 4: 305-314.

MAYR E (1982) The growth of biological thought. Belknap Press, The Harvard University Press, Cambridge, Massachusetts. 974 pp.

MAYR E (1994) Ordering systems. Science 266: 715.

MAYR E (1995) Systems of ordering data. Biology and Philosophy 10: 419-434.

MOLINA JI (1782) Saggio sulla storia naturale del Chili. Stamperia di S. Tommaso d Áquino. Bologna, Italia. 349 pp. [In: Arquealla Mendoza, D.J. (1788). (Traducción en español) Compendio de la Historia Geográfica, Natural y Civil del Reyno de Chile. Primera parte que abraza la historia geográfica y natural. Madrid, España].

NEWMAN WA (1996) Cirripedia; Suborders Thoracica and Acrothoracica. In: Forest J (ed) Traité de Zoologie, Tome VII, Crustaces, Fascicule 2: 453540. Mason, Paris.

NELSON G (1974) Darwin-Hennig classification: A reply to Mayr. Systematic Zoology 23: 452-458.

PADIAN K (1999) Charles Darwin's view of classification in theory and practice. Systematic Biology 48: 352364 .

STOTT R (2003) Darwin and the barnacle. W.W. Norton \& Company, New York. 309 pp.

TOMLINSON JT (1969a) The burrowing barnacles (Cirripedia: Order Acrothoracica). US National Museum Bulletin 296: 1-162.

TOMLINSON JT (1969b) Shell-burrowing barnacles. American Zoologist 9: 837-840.

TOMLINSON JT (1987) The burrowing barnacles (Acrothoracica). In: Southward AJ (ed) Barnacle biology. Crustacean Issues V. 5: 63-71. Belkema, Rottherdam, The Netherlands. 
